\title{
PEMBUDIDAYAAN TANAMAN SAYUR DENGAN MEDIA TANAM PADA POLYBAG DAN PEMANFAATAN LAHAN KOSONG
}

\author{
Dr. Daryono, M.Pd. ${ }^{1}$, Yuniar Mujiwati, M.Pd ${ }^{2}$, Okta Dewi Masita ${ }^{3}$, \\ Muhammad Khuzaemi ${ }^{4}$ \\ ${ }^{1,2)}$ Pendidikan Pancasila dan Kewarganegaraan, Fakultas Pedagogi dan Psikologi, Universitas \\ PGRI Wiranegara Pasuruan \\ ${ }^{3)}$ Pendidikan Bahasa dan Sastra Indonesia, Fakultas Pedagogi dan Psikologi, Universitas PGRI \\ Wiranegara Pasuruan \\ ${ }^{4)}$ Program Studi Pendidikan Agama Islam, Sekolah Tinggi Ilmu Tarbiyah Pasuruan \\ email : daryono.jarwo@gmail.com ${ }^{1}$, yuniar.caliptra@gmail.com, ${ }^{2}$, Oktadewimasita027@gmail.com ${ }^{3}$ \\ Khuzaemimuhammad@gmail.com
}

\begin{abstract}
Abstrak
Permasalahan yang diangkat dalam jurnal ini yakni mengenai pembudidayaan tanaman sayur dengan menggunakan media tanam pada polybag di Dusun Karangasem, Desa Tenggilis Rejo RT 01/RW 04 Kecamatan Gondangwetan Kabupaten Pasuruan dan pemanfaatan lahan kosong di Desa Karangketug Pasuruan. Kegiatan ini bertujuan memberikan pemahaman kepada masyarakat tentang pembudidayaan tanaman dengan menggunakan media tanam tanah pada polybag yang biasa dilakukan di rumah dan memanfaatkan lahan kosong untuk ditanami tanaman toga dan buah. Apalagi pada masa pandemic ini masyarakat dihimbau untuk selalu ada dirumah guna memutus mata rantai penyebaran virus Covid-19. Metode yang digunakan yakni dengan observasi melalui pendekatan berupa sosialisasi kepada masyarakat sekitar. Baik secara individu maupun kelompok masyarakat akan mendapatkan pengalaman dari bidang yang sebelumnya belum pernah dilakukan, sehingga dalam pelaksanaan kegiatan ini harapannya juga akan membawa manfaat pada peningkatan ekonomi pada masa pandemi yaitu dengan bentuk hasil dari penanaman tersebut nanti dapat diperjual belikan.
\end{abstract}

Kata Kunci : Pembudidayaan, Lahan Kosong, Media Polybag

\begin{abstract}
The problem raised in this journal is regarding the cultivation of vegetable plants using planting media in polybags in Karangasem Hamlet, Tenggilis Rejo Village RT 01 / RW 04, Gondangwetan District, Pasuruan Regency and the use of empty land in Karangketug Village, Pasuruan. This activity aims to provide understanding to the community about cultivating plants using soil planting media in polybags which can be done at home and utilizing empty land for planting toga and fruit plants. Especially during this pandemic, people are urged to always be at home to break the chain of spreading the Covid-19 virus. The method used is observation through an approach in the form of socialization to the surrounding community. Both individually and in community groups will gain experience from fields that have never been done before, so that in implementing this activity it is hoped that it will also bring benefits to economic improvement during the pandemic, namely using the results of the planting that can be traded later.
\end{abstract}

Keywords: Cultivation, Vacant Land, Polybag Media

\section{PENDAHULUAN}

Kebutuhan pangan merupakan kebutuhan pokok manusia, kebutuhan ini harus dipenuhi karena terkait dengan kelangsungan hidup manusia. Indonesia saat ini sedang mengalami masa sulit karena Pandemi Covid-19. Kehidupan di masyarakat tidak lagi berjalan secara normal dan tidak lagi seperti yang biasanya dilalui. Banyak aspek dalam kehidupan masyarakat yang terkena dampak dari pandemi ini. Ketahanan pangan merupakan salah satu isu strategis dalam 
pembangunan suatu negara (Simatupang, 2007). Terbatasnya lahan di Dusun Karangasem, Desa Tenggilis Rejo RT 01/RW 04 Kecamatan Gondangwetan, Kabupaten Pasuruan menjadi tantangan membangun kesadaran akan ketahanan pangan bagi rumah tangga. Bahkan dalam level nasional, tantangan membangun ketahanan pangan ini adalah terbatasnya lahan di lingkungan tersebut sehingga bagaimana caranya lahan sekecil apapun agar dapat dijadikan sebagai penanaman. Kegiatan ini berupa penanaman sayur dengan teknik Pembudidayaan tanaman sayur dengan media tanam tanah pada polybag.

Budidaya merupakan kegiatan yang direncanakan untuk melestarikan sumber daya hayati di suatu daerah untuk di ambil dan di manfaatkan hasil panennya. Budidaya tanaman adalah berbagai macam kegiatan pengembangan dan pemanfaatan sumberdaya alam nabati yang dilakukan oleh manusia dengan menggunakan modal, teknologi ataupun dengan sumber daya lainnya untuk menghasilkan suatu produk berupa barang yang bisa memenuhi kebutuhan manusia. (PP RI No 18 Tahun 2010 tentang Usaha Budidaya Tanaman). Dalam hal ini kegiatan yang dilaksanakan oleh Mahasiswa KKN-DR yaitu melakukan pembudidayaan tanaman sayur, buah dan toga. 1) Budidaya tanaman sayur yaitu kegiatan menanam tanaman yang dapat menghasilkan bahan pangan dengan memanfaatkan sumber daya dari tumbuhan yang di tanam. Dari hasil proses produksi menanam ini bisa menghasilkan tanaman yang dapat di konsumsi. Dalam hal ini Mahasiswa melakukan pembudidayaan tanaman sayur berupa sayur kangkung, bayam, terong dan sawi. 2) Budidaya tanaman buah yaitu kegiatan menanam tanaman yang dapat menghasilkan buah-buahan sehingga dari hasilnya bisa mendapatkan keuntungan. Dalam hal ini Mahasiswa melakukan pembudidayaan tanaman buah berupa buah sirkaya dan kelengkeng. 3) Budidaya tanaman toga yaitu kegiatan menanam tanaman yang berkhasiat sebagai obat. Masih banyak orang yang menggunakan obat tradisional untuk menyembuhkan beberapa penyakit dengan cara menanam tanaman obat keluarga ini. Dalam hal ini Mahasiswa melakukan pembudidayaan tanaman toga berupa jahe, sirih, cabai, kunyit dan temulawak.

Media tanam merupakan salah satu faktor penting yang sangat menentukan dalam kegiatan bercocok tanam. Dalam hal ini, mahasiswa menggunakan Media tanam tanah pada polybag untuk budidaya sayur. Bahan-bahan yang digunakan merupakan bahan yang banyak tersedia di alam dan bisa dikerjakan sendiri. Media tanam memiliki fungsi untuk menopang tanaman, memberikan nutrisi dan menyediakan tempat bagi akar tanaman untuk tumbuh dan berkembang.

Menurut KBBI, lahan merupakan tanah terbuka atau tanah garapan yang disediakan untuk permukiman transmigran. Penggunaan lahan merupakan setiap bentuk intervensi (campur tangan) manusia terhadap lahan dalam rangka memenuhi kebutuhan hidupnya baik material maupun spiritual (Arsyad, 1989:207). Hal itu dapat dimanfaatkan untuk dijadikan penanaman secara langsung pada lahan yang kosong tersebut tanpa media tanam tanah pada polybag. Pemanfaatan lahan kosong menjadi salah satu upaya urban farming di Desa Kradenan RT 02/RW 06 Kelurahan Karangketug, Kecamatan Gadingrejo, Kota Pasuruan. Kegiatan ini bertujuan untuk membiasakan diri membangun ketahanan pangan yang dimulai dari rumah dan lingkungan sekitar, serta untuk memenuhi kebutuhan pangan bagi konsumsi rumah tangga masing-masing. Kegiatan ini berupa peremajaan lahan dalam penanaman Toga dan Buah dengan teknik tanam pada lahan kosong.

Adapun tujuan dari tindakan dari kegiatan ini adalah agar masyarakat mendapatkan pengalaman dari bidang yang sebelumnya belum pernah dilakukan, sehingga dalam pelaksanaannya bisa bermanfaat baik dari segi pengalaman maupun peningkatan ekonomi.

\section{METODE}

A. Kegiatan Pembudidayaan Tanaman Sayur dengan media Tanam tanah pada polybag di Dusun Karangasem, Desa Tenggilis Rejo RT 01/RW 04 Kecamatan Gondangwetan, Kabupaten Pasuruan.

Bentuk kegiatan pengabdian yang dilakukan yaitu melakukan observasi terlebih dahulu melalui pendekatan kepada ketua RT untuk menentukan program kerja yang sesuai dengan kondisi di daerah tersebut sehingga bisa bermanfaat bagi warga dalam masa pandemic ini. Setelah dilakukan survey, ditemukan suatu solusi dari permasalahan yang 
ada yaitu melakukan sosialisasi guna membudidayakan tanaman sayur yang harapannya bisa membawa manfaat di saat masa pandemi ini dan langsung mrelakukan kegiatan. Adapun pelaksanaan kegiatan ini terdiri dari :

1. TahapPersiapan

Mempersiapkan perlengkapan untuk tahap pelaksanaan kegiatan yaitu melakukan koordinasi dengan ketua RT Dusun Karangasem, Desa Tenggilis Rejo RT 01/ RW 04, Kecamatan Gondangwetan Kabupaten Pasuruan yang selanjutnya dilakukan sosialisasi kepada masyarakat tentang pembudidayaan tanaman sayur dengan media tanam pada polybag.

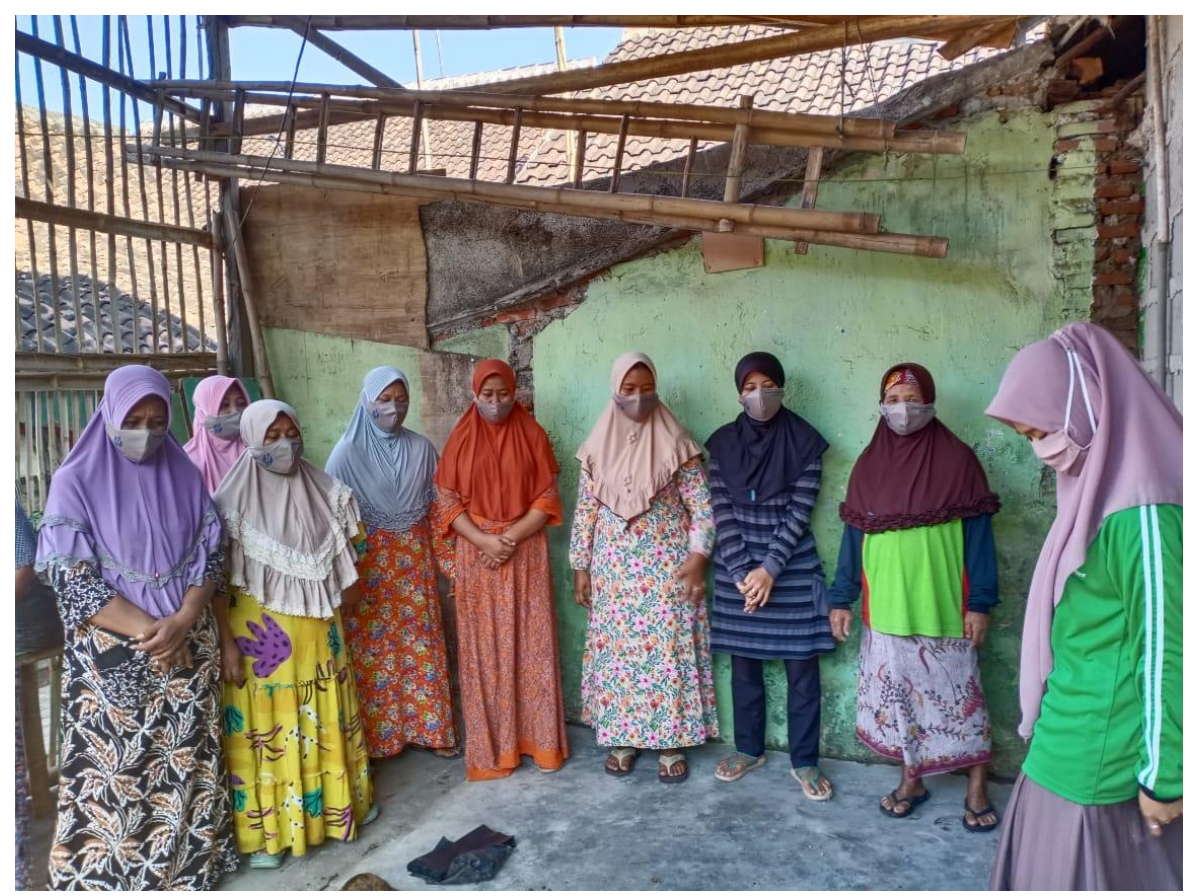

Gambar 1. Sosialisasi Pembudidayaan Tanaman Sayur

2. Pembudidayaan Tanaman Sayur dengan Media tanam tanah pada Polybag

Tahap-tahap yang dilakukan pada kegiatan ini adalah diawali proses pencampuran pupuk dan tanah. Mahasiwa KKN melakukan bersama dengan ibu-ibu warga Dusun Karangasem, kemudian memasukkan campuran tanah tersebut kedalam Polybag dan dan menanam bibit sayur kedalam media tanam pada polybag. Adapun tanaman sayur yang dibudidayakan adalah kangkung, tomat,bayam, sawi, dan terong. Setelah kegiatan penanaman, dilakukan kegiatan penyiraman. Selanjutnya hasil dari penanaman dibagikan pada masyarakat warga desa. Hal ini dilakukan agar warga masyarakat sadar bahwasanya tanpa lahan yang luas pun, tetap bisa melaksanakan kegiatan penanaman dengan menggunakan media tanam pada polybag yang dilakukan di rumah, serta dapat memanfaatkan hasil penanaman sebagai pola makan yang sehat dan bisa di perjualbelikan. 


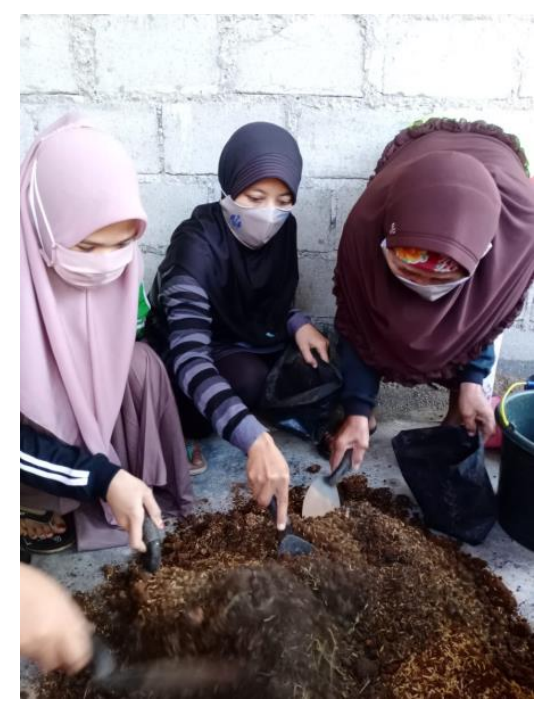

Gambar 2 Pencampuran tanah dan pupuk

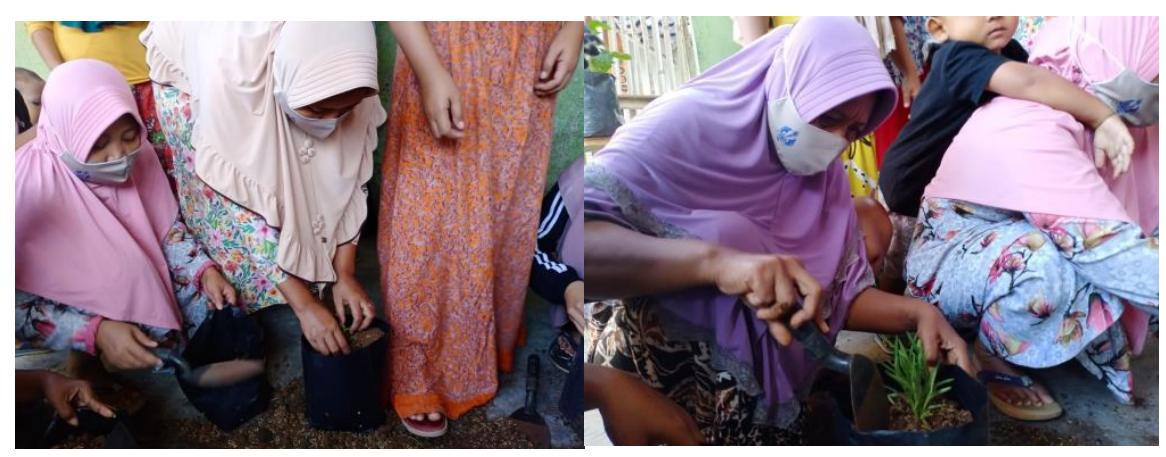

Gambar 3 Penanaman bibit sayur ke dalam polybag

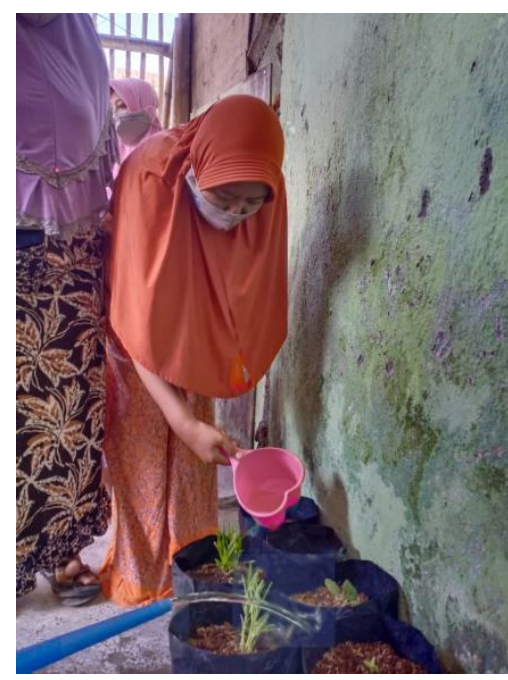

Gambar 4 Penyiraman bibit tanaman 


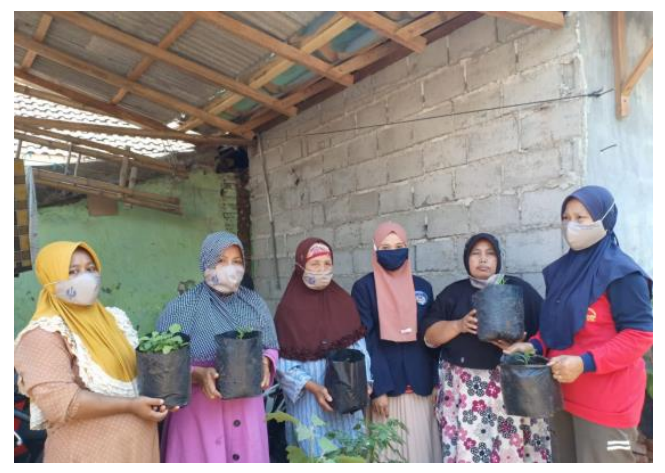

Gambar 5 Pendistribusian tanaman pada warga masyarakat sekitar

B. Kegiatan Pemanfaatan Lahan di Desa Kradenan Kelurahan Karangketug Kecamatan Gadingrejo Kota Pasuruan

1. Peremajaan Lahan

Lahan yang akan digunakan ini adalah lahan kosong yang tidak dimanfaatkan. Banyak bongkahan batu sehingga perlu dilakukan peremajaan lahan untuk menyuburkan lahan agar siap untuk ditanami. Pembersihan bongkahan batu dikerjakan langsung oleh mahasiswa KKN. Selanjutnya dilakukan pencangkulan lahan yang bertujuan agar lahan bisa dengan mudah untuk ditanami.
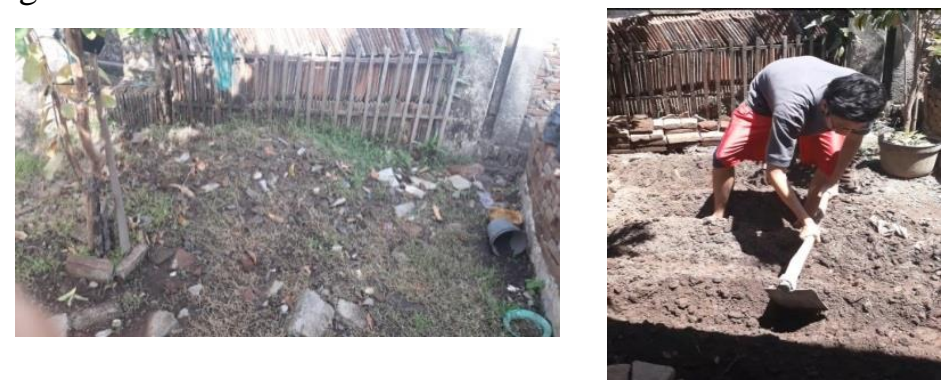

Gambar 6 Lahan Kosong dan Proses Peremajaan Lahan

2. Penanaman Lahan

Adapun jenis tanaman yang akan ditanam adalah tanaman Toga dan tanaman buah Penanaman Toga meliputi jahe, sereh, cabai, temulawak, kunir, pandan. Sedangkan Penanaman tanaman buah srikaya, kelengkeng, jambu
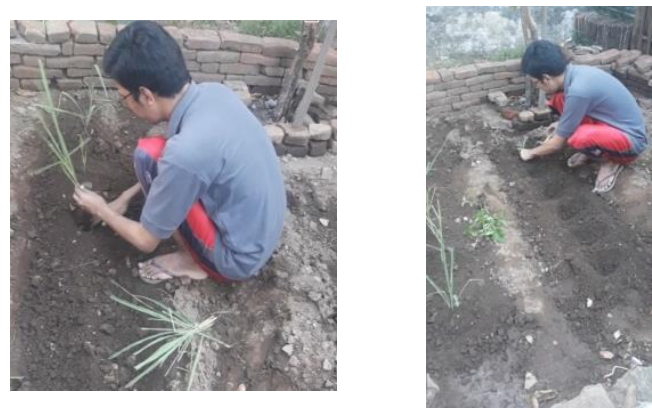

Gambar 5 Proses Penanaman Lahan

3. Perawatan Lahan

Adapun perawatan Lahan dan tanaman dilakukan melalui kegiatan pemuatan pagar Kegiatan ini bertujuan agar lahan aman dari hewan perusak/penggangu. Selanjutnya perawatan lahan dengan tanaman lainnya dilakukan dengan kegiatan penyiraman lahan, agar lahan atau tanaman yang sudah ditanam menjadi subur dan segar. 

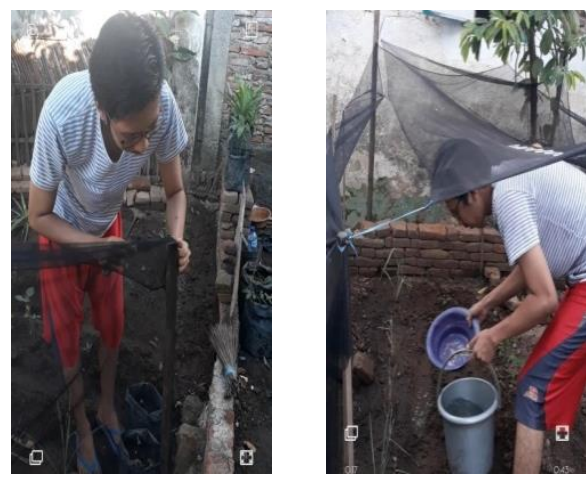

Gambar 6.Pembuatan pagar dan penyiraman

\section{HASIL DAN PEMBAHASAN}

Selama KKN berlangsung, mahasiswa menemui beberapa kendala antara lain pada penanaman menggunakan media tanam pada polybag, kendala yang dihadapi adalah kekurangan bibit yang ditanam sehingga pendistribusian tanaman tidak cukup menjangkau warga masyarakat sekitar. Adapun tindak lanjut program penanaman dengan media tanam menggunakan polybag ini agar tetap terlaksana walaupun terbatas pada lahan sehingga masyarakat bisa menikmati hasil tanaman sayur sendiri sebagai olahan makanan sehat.

Dalam hal peremajaan lahan, kesulitan terbesar adalah banyaknya bongkahan sisa bangunan yang besar dan bongkahan yang terpendam dalam tanah sehingga dengan penggunaan alat manual mengalami kesulitan untuk membersihkannya, sedangkan pada perawatan tanaman adalah ketika adanya hewan perusak/pengganggu yang masuk dan merusak tanaman.

Hasil pelaksanaan program KKN DR yang dilaksanakan di Dusun Karangasem, Desa Tenggilis Rejo RT01/RW04 Kecamatan Gondangwetan, Kabupaten Pasuruan dan di Desa Kradenan Kelurahan Karangketug Kecamatan Gadingrejo Kota Pasuruan,berjalan lancar serta mendapat respon yang baik dari pihak warga masyarakat dan telah memberikan hasil-hasil yang positif.

\section{SIMPULAN}

Setelah dilaksanakan KKN olehMahasiswa UNIWARA dan STIT PGRI Pasuruan harapannya masyarakat dapat memahami akan adanya kesempatan walau sekecil apapun yang berada disekitar kita khususnya pada masa pandemi ini, selain mendapatkan pengalaman juga akan penanaman tanaman menggunakan media tanan tanah pada polybag, juga dapat mencontoh akan pemanfaatan lahan kosong yang tidak layak, menjadi lebih menguntungkan dengan cara di kelola dengan baik dan juga dapat meningkatkan perekonomian masyarakat dari hasil penanaman lahan. Baik secara individu maupun kelompok mahasiswa mendapatkan pengalaman belajar yang sangat berharga melalui keterlibatan di masyarakat yang secara langsung menemukan, merumuskan, memecahkan dan menanggulangi permasalahan yang ada.

\section{SARAN}

Penulis juga mengharapkan saran dengan adanya kegiatan yang sudah dilakukan oleh mahasiswa melalui program KKN DR, sehingga bisa mewujudkan hasil yang jauh lebih baik dan dapat bermanfaat bagi masyarakat.

\section{DAFTAR PUSTAKA}

Arsyad, Sitanala. 1989. Konservasi Tanah dan Air. Bogor : Institut Pertanian Bogor. Kamus Besar Bahasa Indonesia

Peraturan Pemerintah RI. Nomor 18 Tahun 2010. Tentang Usaha Budidaya Tanaman. Bandung, Citra Umbara.

Simatupang, T.M. 2007. Ekonomi Kreatif Berperan Penting. Pikiran Rakyat, 13 September 2007. 